University of Wollongong

Research Online

Faculty of Engineering - Papers (Archive)

Faculty of Engineering and Information

Sciences

May 2006

\title{
Selection of potential reactive materials for a permeable reactive barrier for remediating acidic groundwater in acid sulphate soil terrains
}

\author{
A. N. Golab \\ University of Wollongong, golab@uow.edu.au \\ M. A. Peterson \\ University of Wollongong \\ Buddhima Indraratna \\ University of Wollongong, indra@uow.edu.au
}

Follow this and additional works at: https://ro.uow.edu.au/engpapers

Part of the Engineering Commons

https://ro.uow.edu.au/engpapers/307

\section{Recommended Citation}

Golab, A. N.; Peterson, M. A.; and Indraratna, Buddhima: Selection of potential reactive materials for a permeable reactive barrier for remediating acidic groundwater in acid sulphate soil terrains 2006.

https://ro.uow.edu.au/engpapers/307

Research Online is the open access institutional repository for the University of Wollongong. For further information contact the UOW Library: research-pubs@uow.edu.au 


\title{
Selection of potential reactive materials for a permeable reactive barrier for remediating acidic groundwater in acid sulphate soil terrains
}

\author{
A.N. Golab ${ }^{1}$, M.A. Peterson ${ }^{2} \&$ B. Indraratna ${ }^{3}$ \\ ${ }^{1}$ Postdoctoral Research Fellow, Faculty of Engineering, University of Wollongong, Wollongong, NSW 2522, \\ Australia (e-mail: golab@uow.edu.au) \\ ${ }^{2} \mathrm{PhD}$ Candidate, Faculty of Engineering, University of Wollongong, Wollongong, NSW 2522, Australia \\ ${ }^{3}$ Professor of Civil Engineering, University of Wollongong, Wollongong, NSW 2522, Australia
}

\begin{abstract}
A permeable reactive barrier is being designed to remediate leachate from acid sulphate soils. The current research relates to testing of alkaline materials for use in the barrier, with an emphasis on waste materials. Thirteen alkaline materials including recycled concrete, limestone, calcite-bearing zeolitic breccia, blast furnace slag, lime and fly ash were tested. The batch tests involved several phases, such as leaching in deionized water to characterize the soluble components of the materials and the $\mathrm{pH}$ that each material could achieve. Another phase involved testing with acidic water $(\mathrm{pH} 3)$ to determine the acid leachable components of the materials and the $\mathrm{pH}$ after neutralization. The $\mathrm{pH}$ achieved by each reactive material was controlled by the reaction kinetics of the dominant alkaline mineral. The concretes, fly ash, and air-cooled blast furnace slag (ACBFS) all achieved a $\mathrm{pH}$ that is consistent with the dissolution of lime (pH 11 to 12). The limestone and zeolitic breccias all achieved a pH consistent with the dissolution of calcite ( $\mathrm{pH}$ c. 7.4). Based on the results of the batch tests, a short-list of materials was selected that included a recycled concrete, ACBFS, three zeolitic breccias and limestone. The short-listed materials were examined for exhaustion of neutralizing ability by repeatedly replacing the acidic water and monitoring the resultant $\mathrm{pH}$. The precipitates that formed during this process were analysed to characterize the chemical reactions that occurred during the tests. Based on the results, the recycled concrete was selected for testing in columns that will simulate flow conditions through the barrier.
\end{abstract}

Keywords: groundwater contamination, laboratory tests, remediation

In Australia the acidification of coastal rivers is a well-recognized environmental, economic and social problem. Acidification is caused by the oxidation of soils that contain iron sulphides (e.g. pyrite), commonly referred to as acid sulphate soils (ASS). Pyrite is relatively chemically inert if left undisturbed and submerged in anaerobic groundwater. However when the groundwater table falls below the level of the sulphidic soil horizon, atmospheric oxygen oxidizes the pyrite to form sulphuric acid. The acid mobilizes iron from the pyrite and aluminium ions from the soil into the groundwater, leading to problems such as loss of agricultural and fishery productivity and damage to steel and concrete infrastructure. As an example of the extent of the problem, White et al. (1997) conservatively estimate that Australia has 3 million hectares of ASS.

Oxidation of ASS can occur naturally but it is exacerbated by the use of deep flood mitigation drains. Over the past century high-density drainage systems have commonly been installed in low-lying coastal areas of Australia to increase the rate of lateral flood water outflow and generate farming land in areas that would otherwise be regularly tidally inundated. The drains are commonly fitted with one-way floodgates that discharge the drain-water into the nearby waterway at low tide. This causes a lowering of the watertable below its natural position. In the drained upper soil layers, oxygen is entrained. Hence, through causing draw-down of the surrounding groundwater, one-way floodgates expose ASS to oxidizing conditions.

The problem is exacerbated by seasonal fluctuations in the position of the watertable: when dry conditions dominate, the watertable level drops and large volumes of sulphidic soil are exposed to oxidizing conditions. When rainfall recharges the groundwater, the acid, iron and aluminium released by oxidation can be mobilized and transported to the drains (Indraratna et al. 2001). Various remediation techniques that alter the level of the watertable or allow tidal buffering (Indraratna et al. 2005) have previously been implemented. These techniques however are not suited to very low-lying areas that are subjected to flooding. The focus of the current research is to intercept and remediate the acidic groundwater before it reaches the drain using a permeable reactive barrier (PRB) without altering the level of the watertable.

A PRB can consist of a trench filled with reactive media and covered again with top-soil to allow existing land-use to continue. The barrier intersects the flow-path of contaminated groundwater and ameliorates the groundwater through physical, chemical and/or biological processes, including precipitation, sorption, oxidation/reduction, fixation, and degradation. PRBs are passive, in-situ remediation systems that do not 


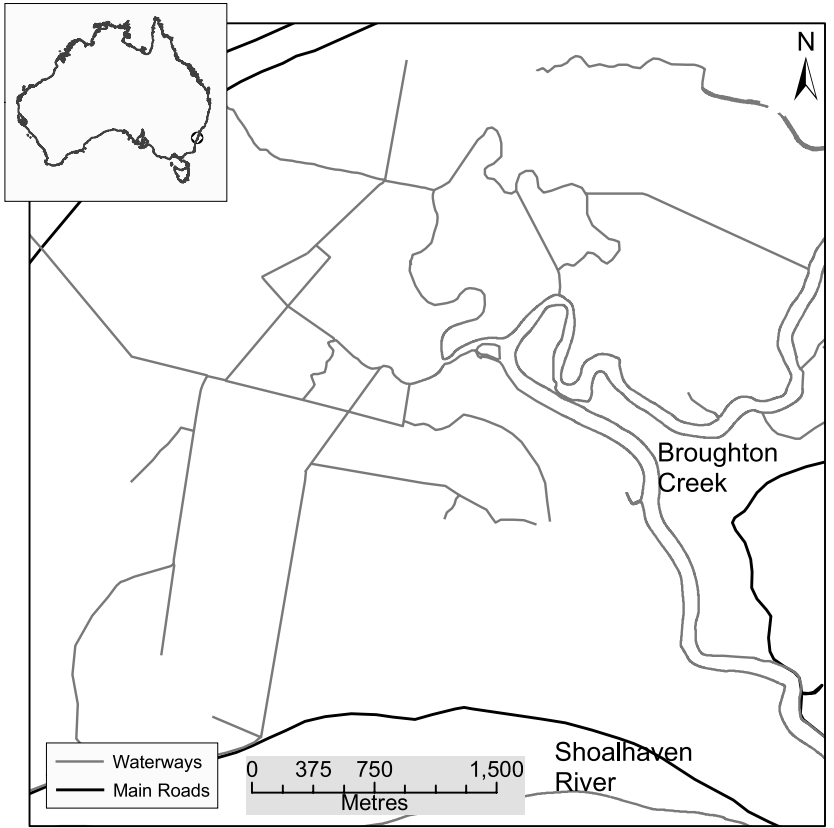

Fig. 1. Map showing the location of the study site in southeastern Australia. Note that the straight waterways marked in the map are man-made flood mitigation drains.

require sustained energy input, and are therefore relatively inexpensive. The only maintenance that could potentially be required is the replacement of the reactive material if the reactive potential is exhausted or it is clogged by precipitates (Vidic 2001). The type of reactive material used within the PRB depends on the groundwater contaminant and in many cases a mixture of reactive media is the most effective. The materials (chemical and/or biological reagents or catalysts) are chosen to react with the contaminants to render them harmless by the time they pass out the other side of the PRB.

Since 1996 over 40 PRBs have been installed worldwide (Wilkin et al. 2003). The majority of PRBs are used to treat groundwater contaminated with chlorinated volatile organic compounds (e.g. Wilkin et al. 2003) and acid mine drainage (e.g. Gibert et al. 2003). Research is beginning in Australia (e.g. Desmier et al. 2002) into the use of PRBs to treat ASS.

Batch tests have been used by many researchers to determine the effectiveness of reactive materials (e.g. Waybrant et al. 1998; Bernier 2005). The current paper describes the process for selecting reactive materials for use in a PRB for remediating groundwater from ASS. The study site consists of farming land that was drained in the late 1960s in southeastern New South Wales, Australia (Fig. 1). The main contaminants in the groundwater are acidity, soluble aluminium, and ferric iron. The reactive material must therefore be able to increase the $\mathrm{pH}$ of the groundwater to a level that causes the iron and aluminium to precipitate out of solution. A supply of anions/complexes for the iron and aluminium to react with to form insoluble precipitates is required
Table 1. The composition of six reactive materials

\begin{tabular}{|c|c|}
\hline Sample & Main Components \\
\hline Concrete3 & Portlandite, Quartz, Flyash, Shale \\
\hline Zeolite3 & $\begin{array}{l}\text { Quartz, Laumontite, Albite, Calcite, Chlorite, } \\
\text { Goethite }\end{array}$ \\
\hline Zeolite8 & $\begin{array}{l}\text { Quartz, Laumontite, Albite, Calcite, Chlorite, } \\
\text { Goethite }\end{array}$ \\
\hline Slag1 & Air-cooled blast furnace slag \\
\hline Limestone & Calcite \\
\hline Breccia1 & Quartz, Albite, Goethite, Chlorite, Albite \\
\hline
\end{tabular}

and the reactive material must provide reactive sites for the precipitation to take place. The reactive material must also have a permeability and effective porosity that allows the groundwater to pass freely through the barrier. With time, the reactive material may be consumed by the reactions that take place and the reactive sites may become armoured by the precipitates that form. Therefore one important aspect is the longevity of the material. A further desirable aspect of the reactive material is that it is a waste material. This allows the dual benefit of remediation of the acidic groundwater and utilization of a waste material.

In summary, the aim of this research is to select a reactive material for a PRB based on the ability to neutralize acidity and remove $\mathrm{Al}$ and $\mathrm{Fe}$ ions from the groundwater. The material must also be a locally abundant waste material with a suitable grain size to encourage flow through the PRB. The selection will be made based on the results of three phases of batch tests.

\section{Reactive materials}

This section contains a discussion of each group of reactive materials, listed in Appendix 1. The Fly ash and Lime were included purely to allow comparison with other studies. The materials that were considered in Batch Test 3 were analysed by X-ray diffraction (XRD) and the results are presented here to allow discussion on the reactions between the reactive materials and drain-water (Table 1).

Fly ash Fly ash is a by-product of the combustion of finely divided coal in power stations. It is extracted from the exhaust gases of the power station by electro-static precipitators. Fly ash consists predominantly of very fine powdery siliceous and aluminous material. Fluidizedbed combustion ash was used in the current study and this ash contains a high percentage of lime (Siriwardane et al. 2003).

Lime $\left[\mathrm{CaO}\right.$ or $\left.\mathrm{Ca}(\mathrm{OH})_{2}\right]$ is significantly more soluble than limestone and reacts much more rapidly with acid. Lime dissolves according to the following equation: 


$$
\mathrm{Ca}(\mathrm{OH})_{2} \stackrel{K_{s p}}{\longleftrightarrow} \mathrm{Ca}^{2+}+2 \mathrm{OH}^{-}
$$

The reaction is so rapid that it is considered in equilibrium. Therefore the theoretical $\mathrm{pH}$ limit of neutralization can be ascertained directly from (Ring et al. 1996):

$$
\left[H^{+}\right]_{\lim i t}=\frac{K_{w}}{\left(\frac{K_{s p}}{2}\right)^{\frac{1}{3}}}
$$

The $\mathrm{K}_{\mathrm{sp}}$ is the solubility product equilibrium constant for lime and equals -5.19 (Baes \& Mesmer 1976) and $\mathrm{K}_{\mathrm{W}}$ is the dissociation constant of water. Therefore the theoretical limit of $\mathrm{pH}$ for the neutralization of acidic waters with lime is $\mathrm{pH}=12.17$.

In the case of limestone (predominately $\mathrm{CaCO}_{3}$ ), the following dissolution reactions operate:

$$
\begin{aligned}
& \mathrm{CaCO}_{3}+\mathrm{H}^{+} \stackrel{k_{1}}{\longleftrightarrow} \mathrm{Ca}^{2+}+\mathrm{HCO}_{3}^{-} \\
& \mathrm{CaCO}_{3}+\mathrm{H}_{2} \mathrm{CO}_{3} \stackrel{k_{2}}{\longleftrightarrow} \mathrm{Ca}^{2+}+2 \mathrm{HCO}_{3}^{-} \\
& \mathrm{CaCO}_{3} \stackrel{k_{3}}{\longleftrightarrow} \mathrm{Ca}^{2+}+\mathrm{CO}_{3}^{2-}
\end{aligned}
$$

The rate constants for the reverse reactions of 3, 4 and 5 are $k_{-1}, k_{-2}$ and $k_{-3}$ respectively.

$$
\begin{aligned}
& R_{f}=k_{1}\left[\mathrm{H}^{+}\right]+k_{2}\left[\mathrm{H}_{2} \mathrm{CO}_{3}\right]+k_{3} \text { (6) forward rate } \\
& R_{b}=k_{-1}\left[\mathrm{Ca}^{2+}\right]\left[\mathrm{HCO}_{3}^{-}\right]+k_{-2}\left[\mathrm{Ca}^{2+}\right]\left[\mathrm{HCO}_{3}^{-}\right]^{2}+ \\
& k_{-3}\left[\mathrm{Ca}^{2+}\right]\left[\mathrm{CO}_{3}^{2-}\right] \text { (7) backward rate }
\end{aligned}
$$

Chou et al. (1989) extensively studied these reactions and experimentally determined that the important rate constants are $k_{1}, k_{2}, k_{3}$ and $k_{-3}$. The overall rate of reaction in acid conditions will depend on the forward rate constants $k_{1}, k_{2}$ and $k_{3}$ because the carbonate concentration at low $\mathrm{pH}$ will be negligible. The rate constants for limestone are $\log k_{1}=-4.05, \log k_{2}=-7.30$ and $\log k_{3}=-10.19$ (Chou et al. 1989).

The theoretical $\mathrm{pH}$ limit for the neutralization of acidic waters by limestone is 6.14 , as determined from Equation 8. In the batch tests of Bernier (2005), treatment of acid mine drainage by calcite (marble) reached a maximum $\mathrm{pH}$ of 6 .

$$
\left[H^{+}\right]_{\lim i t}=\frac{k_{3}}{k_{1}}
$$

Recycled concrete Concrete generally consists of Portland cement, aggregate of rock and sand, and water. It may also contain supplementary cementitious materials including fly ash, ground blast furnace slag and silica fume. Portland cement is made by heating finely ground limestone and finely divided clay at high temperatures. The product generally contains approximately 65-70\% $\mathrm{CaO}, 18-24 \% \quad \mathrm{SiO}_{2}, 3-8 \% \quad \mathrm{Fe}_{2} \mathrm{O}_{3}, 3-8 \% \quad \mathrm{Al}_{2} \mathrm{O}_{3}$ plus smaller proportions of minor oxides (for example, $\mathrm{Na}_{2} \mathrm{O}, \mathrm{K}_{2} \mathrm{O}, \mathrm{MgO}$, etc.). The lime content of the cement ensures that concrete has a high acid neutralizing capacity and the supplementary materials and aggregate component may also contribute if they contain fly ash, slag or rocks containing neutralizing minerals.

Lime The Lime used was hydrated lime $\left[\mathrm{Ca}(\mathrm{OH})_{2}\right]$ that was in a powdered form. The Lime has a high neutralizing capacity, as discussed in the section on fly ash.

Zeolitic material and breccia This group of five materials refers to a volcanic breccia that formed around the margins of a latite flow, and as pipes through the latite, in southeastern NSW, Australia. The breccia contains abundant amygdales that are rich in zeolites and calcite. The dominant zeolite is laumontite $\left(\mathrm{CaAl}_{2} \mathrm{Si}_{4} \mathrm{O}_{12}\right.$. $\left.4 \mathrm{H}_{2} \mathrm{O}\right)$. The matrix of the breccia is composed of haematite, laumontite and quartz and is cemented by laumontite and calcite (Peterson 1999). At $\mathrm{pH}<8$, laumontite reacts with $\mathrm{H}^{+}$to form Ca-montmorillonite plus $\mathrm{H}_{4} \mathrm{SiO}_{4}$, calcium ions and water (Senderov 1988). Therefore, laumontite has the ability to neutralize acidity and transform into clay.

Several authors have stated that zeolites are suitable reactive materials for use in PRBs (e.g. Park et al. 2002). Jacobs \& Forstner (1999) showed, using $\mathrm{Pb}^{2+}$ as an example, that natural zeolites are capable of immobilizing large amounts of cationic pollutants by sorption. Park et al. (2002) found that the zeolite clinoptilolite is suitable for use in PRBs to treat groundwater contaminated with ammonium and/or heavy metals. Jacobs \& Waite (2004) investigated clinoptilolite as a reactive material in PRBs using batch and column experiments and found that it can efficiently demobilize iron and manganese from groundwater.

Blast furnace slag Blast furnace slag (BFS) is a by-product from the reduction of iron ores to produce molten iron and molten slag. The slag is normally cooled either by:

(i) pouring the molten slag into beds and aircooling to form a crystalline rock-like structure known as Air-Cooled Blast Furnace Slag, or; 
Table 2. Chemical composition of slag from Port Kembla steelworks after Muston (1991)

\begin{tabular}{|c|c|c|c|}
\hline Component & $\%$ & Component & $\%$ \\
\hline $\mathrm{SiO}_{2}$ & 36.0 & $\mathrm{Na}_{2} \mathrm{O}$ & 0.33 \\
\hline $\mathrm{Al}_{2} \mathrm{O}_{3}$ & 9.1 & $\mathrm{NiO}$ & $<0.002$ \\
\hline As & 0.003 & $\mathrm{~Pb}$ & 0.01 \\
\hline B & 0.004 & $\mathrm{P}_{2} \mathrm{O}_{5}$ & 0.07 \\
\hline $\mathrm{BaO}$ & 0.112 & $\mathrm{Nb}$ & $<0.01$ \\
\hline $\mathrm{CaO}$ & 38.6 & $\mathrm{SO}_{3}$ & 1.25 \\
\hline $\mathrm{Cd}$ & $<0.0005$ & $\mathrm{Sb}$ & $<0.02$ \\
\hline $\mathrm{Co}_{3} \mathrm{O}_{4}$ & 0.002 & $\mathrm{Sn}$ & $<0.01$ \\
\hline $\mathrm{Cr}_{2} \mathrm{O}_{3}$ & 0.011 & $\mathrm{SrO}$ & 0.047 \\
\hline $\mathrm{CuO}$ & 0.005 & $\mathrm{TiO}_{2}$ & 0.46 \\
\hline $\mathrm{Fe}_{2} \mathrm{O}_{3}$ & 0.48 & $\mathrm{~V}_{2} \mathrm{O}_{5}$ & 0.005 \\
\hline $\mathrm{K}_{2} \mathrm{O}$ & 0.47 & $\mathrm{Se}$ & $<0.01$ \\
\hline $\mathrm{MgO}$ & 6.8 & $\mathrm{ZnO}$ & 0.004 \\
\hline $\mathrm{Mn}_{2} \mathrm{O}_{4}$ & 0.78 & $\mathrm{ZnO}_{2}$ & 0.032 \\
\hline Mo & 0.001 & & \\
\hline
\end{tabular}

(ii) rapid water quenching to form a glassy, sand-type material, known as Granulated Blast Furnace Slag.

Blast furnace slag is a non-metallic by-product that consists primarily of oxides of silicon, calcium, aluminium and magnesium. It also contains low levels of heavy metal oxides, but according to Sirman Associates Limited (1985) these are fixed in the matrix of the silica melt within the fabric of the blocks of slag. The chemical composition of slag from the Port Kembla steelworks in southeastern Australia is shown in Table 2 and the slag tested for the current study is from the same location.

Muston (1991) monitored the leachate from three large slag emplacements, two of about 120000 tonnes and one of about 20000 tonnes, over an eight month period and the effect of the leachate on the receiving water bodies. The discharge had higher levels of the following parameters than the receiving waters: electrical conductivity, sulphate, sulphide, chloride, total dissolved solids, biochemical oxygen demand, total hardness, nitrate, calcium, magnesium, and sodium but there was no increase in $\mathrm{pH}$, soluble iron, COD or metals.

The results indicated a gradual release of dissolved material that was enhanced by heavy rainfall. The implication is that the majority of the available soluble components of the slag are contained in vesicles and fractures within the slag. With wetting and drying, evaporation moves small quantities of soluble components to the surface, and it is dissolved with the next wetting. Therefore, so long as the slag is kept wet, the gradual release of soluble material will not occur.

A significant limitation to the use of slag in the PRB is that within about six months of placement in the field, it cements itself together thereby significantly limiting the surface area that is exposed for reaction (Sirman Associates Limited 1985).
Limestone Limestone generally consists of fairly pure calcite. The dissolution of limestone and the kinetics of acid neutralization are discussed in the section on fly ash. Limestone has been tested for use as a reactive material for treating acidic groundwater by several authors (e.g. Amos \& Younger 2003; Gibert et al. 2003). Waybrant et al. (1998) performed batch reactions on simulated acidic groundwater using eight different reactive mixtures. The reactive mixtures each contained agricultural limestone, silica sand, an organic source and a bacterial source. Concentrations of dissolved $\mathrm{Fe}$ in the water were depleted within hours to days (Waybrant et al. 1998). Amos \& Younger (2003) batch tested four reactive mixtures for a $\mathrm{PRB}$ to treat $\mathrm{AMD}$ run-off, including limestone chips and found that the presence of limestone increased the neutralizing capacity and more efficiently removed metals from the water. Gibert et al. (2003) tested a mixture of reactive materials, including limestone in a PRB to treat AMD. The PRB was successful in removing metals from the AMD groundwater plume due to $\mathrm{pH}$ increases causing metal (oxy)hydroxides to precipitate, which adsorb other metals onto the surface of the reactive material.

\section{Laboratory procedures}

Three sets of batch tests were performed (Fig. 2). The first batch test involved four reactive materials that were types of blast furnace slag, concrete, and weathered volcanic breccia. All were carried through to the second batch test which involved a total of 13 reactive materials, as described in Appendix 1. The third batch test was on six of the best performing reactive materials and tested the longer term neutralizing capacity of each material with successive volumes of acidic drain-water. In preparation for each batch test, the reactive materials were individually crushed to conform to the grain size distribution curve in Figure 3, except for Lime and Fly ash because they were supplied in powdered form. The grain size distribution that was chosen is based on commercially available distributions for aggregate fines. The acidic drain-water was collected from deep drains in acid sulphate soil and has a similar $\mathrm{pH}$ to the groundwater $(\mathrm{pH}=3$ to 3.2$)$ but is much easier to extract. In each case the experiments were conducted in closed cells to simulate the anaerobic conditions that will be generated in the PRB, although some air entered the jars during the sampling process.

\section{Batch Test 1}

The first batch tests were an indicative test of the remedial potential of four reactive materials. Sixty grams of reactive material was placed into each of four glass jars, which were then filled with acidic drain-water $(\mathrm{pH}=3)$ from the acid sulphate soil field site. After 


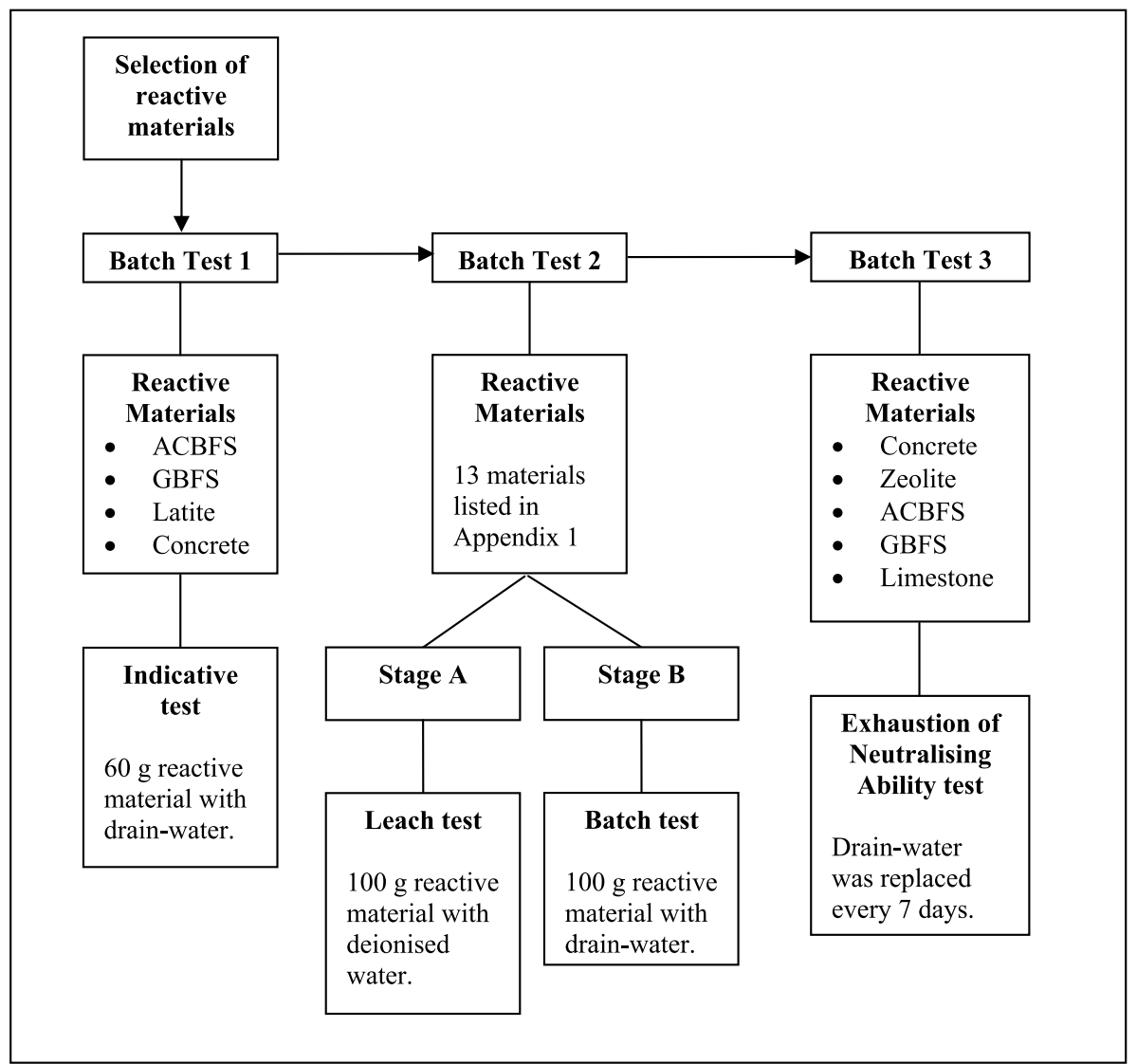

Fig. 2. Outline of methodology for batch tests. ACBFS refers to air-cooled blast furnace slag and GBFS refers to granulated blast furnace slag.

23 days, the $\mathrm{pH}$ of the supernatant was measured. The material was allowed to react with the acidic water for three weeks to allow equilibration to take place prior to testing.

\section{Batch Test 2}

The second batch tests were carefully planned and executed and consisted of two stages (Fig. 2). Stage A was a leach test in deionized water and stage $\mathrm{B}$ was a test of the reactive potential with acidic drain water.

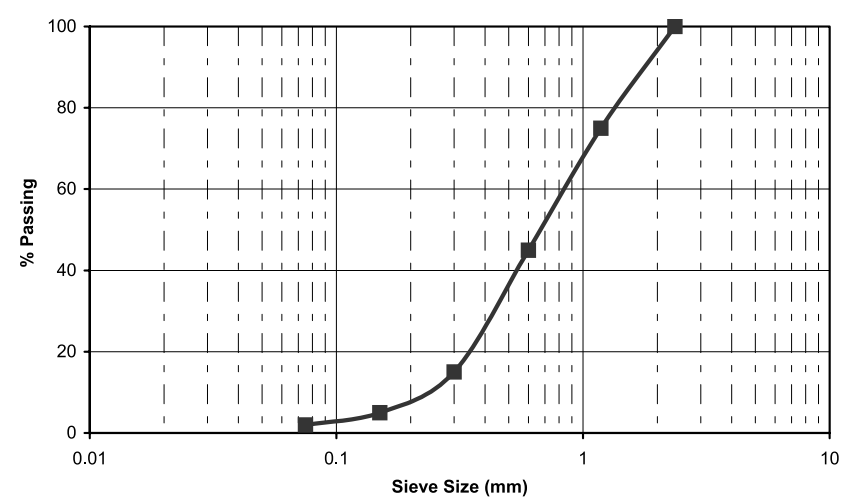

Fig. 3. Average particle size distribution curve for reactive materials.
Stage A Stage A involved a simple leach test of the reactive materials in $1 \mathrm{~L}$ high density polyethylene (HDPE) bottles. Into each HDPE bottle, $100 \mathrm{~g}$ of reactive material was added and then the bottle was filled with deionized (milliQ) water. The $\mathrm{pH}$ of the water in each bottle was measured every hour for the first half day, then once a day for the first week and then after 14, 21,28 , and 53 days. A $100 \mathrm{~mL}$ sample of the water was extracted after 24 hours, 7, 28, and 53 days. Following each $\mathrm{pH}$ reading, the jars were turned end-over-end to ensure complete mixing of the deionized water and reactive materials. The samples were filtered under pressure through a $0.45 \mu \mathrm{m}$ membrane and $100 \mathrm{~mL}$ was acid digested (using $5 \mathrm{~mL}$ of concentrated $\mathrm{HNO}_{3}$ ) then analysed by atomic absorption spectroscopy (AAS). One fraction was acidified to $5 \%$ acidity using concentrated $\mathrm{HNO}_{3}$ and refrigerated in high quality plastic bottles until analysis by inductively coupled plasma atomic emission spectroscopy (ICPAES). The purpose of the leach tests was to determine the leachable component of each reactive material in neutral $\mathrm{pH}$, deionized water.

Stage B Stage B involved the mixing of acidic drainwater, from the acid sulphate soil affected field site, with the reactive materials to determine the effectiveness of each material in removing the contaminants. Thirteen $100 \mathrm{~g}$ samples of reactive material were placed into 
$600 \mathrm{~mL}$ glass jars. Each jar was labelled with the reactive material and filled with acidic drain-water $(\mathrm{pH} c .3)$. An extra $600 \mathrm{~mL}$ glass jar was filled with drain-water to provide a control for the experiment. The $\mathrm{pH}$ of the water in each bottle was measured every hour for the first half day, then once a day for the first week and then after 14, 21 and 28 days. A sample of the water was extracted after 24 hours, 7 days and 28 days.

Seven of the 13 reactive materials were chosen, based on the results at the 28th day, to participate in extended testing (see discussion of results below). As a result, $\mathrm{pH}$ readings were taken in these seven jars for another few weeks. Water samples were also collected from four of the jars on the 52nd day and from the other three jars on the 62 nd day. Following each $\mathrm{pH}$ reading, the jars were turned end-over-end to ensure complete mixing of the drain-water and reactive materials. The samples were filtered through $0.45 \mu \mathrm{m}$ membranes, acidified with $\mathrm{HNO}_{3}$ and refrigerated in high quality plastic bottles until analysis. The purpose of the batch tests with the drain-water is to determine the remedial potential of the reactive material and to generate a shortlist of reactive materials to be tested using column tests.

Batch Test 3 The third stage of the batch tests involved exhaustion of neutralizing ability tests. These tests were conducted on six of the samples used for the batch tests (see Appendix 1). Sixty-two days after the batch tests began, the liquid was siphoned out of each of the six jars and the precipitates that had formed were removed and discarded. The jars were then refilled with drain-water and the $\mathrm{pH}$ was tested. Subsequently the $\mathrm{pH}$ was tested every seven days before the water was siphoned out of the jars, the precipitates were collected then the jars were refilled for a total of 56 days. The precipitates were combined from each of these collection periods and refrigerated. After the final collection, the precipitates were oven dried and then acid digested in $10 \% \mathrm{HNO}_{3}$ and analysed by ICPAES.

\section{Results}

\section{Batch Test 1}

The $\mathrm{pH}$ of the drain-water and the supernatants from four reactive materials after 23 days are given in Table 3.

\section{Batch Test 2}

Stage $A$ The results of the leachate tests are shown in Table 4 and Figure 4 . Table 4 shows the concentrations of a suite of elements in the leachates, as determined by ICPAES, for a selection of reactive materials after 53 days for Concrete3, Zeolite $3 \& 8$ and Slag1 and after 63 days for Slag2, Limestone and Breccia1. Figure 4 shows the leachate $\mathrm{pH}$ and concentrations of $\mathrm{Fe}$ and $\mathrm{Al}$,
Table 3. $p H$ of drain-water and reactive materials after 23 days in acidic drain-water for the indicative batch test

\begin{tabular}{lr}
\hline Sample & pH \\
\hline Drain-water & 2.18 \\
Concrete1 & 14.75 \\
Slag1 & 13.03 \\
Slag2 & 6.04 \\
Breccia1 & 7.47 \\
\hline
\end{tabular}

as determined by AAS, after 28 days from each of the 13 reactive materials. The initial $\mathrm{pH}$ of the deionized water was 5.6.

Stage $B$ Figure 5 shows the variation in pH over 28 days in the batch tests for the 13 reactive materials and the drain-water blank. During the first week a considerable amount of variation occurred in the $\mathrm{pH}$ of most samples and after that the majority of samples plateaued with the notable exception of Slag2. Figures $6 \mathrm{a}, \mathrm{b}$ and $\mathrm{c}$ show the $\mathrm{pH}$ and the concentration of $\mathrm{Fe}, \mathrm{Al}$ and $\mathrm{Ca}$ respectively after seven days in the batch tests. Table 5 shows the concentrations of a suite of elements, as determined by ICPAES, for seven selected reactive materials after 28 days. The $\mathrm{pH}$ of the seven samples chosen for the extended testing are shown in Figure 7.

\section{Batch Test 3}

Figure 8 shows the $\mathrm{pH}$ of the six samples in the exhaustion of neutralizing ability tests. Table 6 lists the composition of the precipitates that formed with the six reactive materials. The precipitates were collected nine times and combined over the 56 day period.

\section{Discussion of test results}

\section{Batch Test 1}

The results of the indicative batch test with acidic drain-water after 23 days (Table 3) indicate that all four reactive materials (Concrete1, Slag1, Slag2 and Breccia1) successfully neutralized the acidity over this timescale. Based on these results, the second stage of batch tests was initiated with fresh samples of these four materials and an additional nine reactive materials.

\section{Batch Test 2}

Stage $A$ The Fly ash, three concretes, Lime, and the two slags established a $\mathrm{pH}$ in the deionized water of above 11 (Fig. 4). In the cases of the Lime, concretes, and Fly ash, the high $\mathrm{pH}$ is due to the dissolution of $\mathrm{Ca}(\mathrm{OH})_{2}$ (Siriwardane et al. 2003). The slags also contain highly alkaline components that are readily soluble (Fig. 4) and 
according to Sirman Associates Limited (1985), this is likely to be $\mathrm{CaO}$. When the $\mathrm{CaO}$ in slag encounters water, reaction (9) occurs. The equilibrium $\mathrm{pH}$ that is achieved after buffering with atmospheric oxygen is 10.2 (Sirman Associates Limited 1985). In a similar test by Lum \& Bhupsingh (1983), whereby a 30-50 $\mathrm{mm}$ piece of BFS was placed in distilled water, within three hours the $\mathrm{pH}$ had risen to 10.6.

$$
\mathrm{CaO}+\mathrm{H}_{2} \mathrm{O} \leftrightarrow \mathrm{Ca}^{2+}+2 \mathrm{OH}^{-}
$$

Two materials performed noticeably poorly in terms of lower $\mathrm{pH}$ and higher concentrations of $\mathrm{Fe}$ and $\mathrm{Al}$, these were Zeolite7, and Breccia4.

Table 4 displays the composition of the supernatant for a select few reactive materials. The concrete released a considerable quantity of $\mathrm{Na}, \mathrm{K}, \mathrm{Ca}, \mathrm{Sr}, \mathrm{Al}$, and $\mathrm{S}$ as well as trace amounts of $\mathrm{Ti}, \mathrm{V}, \mathrm{Cr}, \mathrm{Fe}$, and $\mathrm{Cu}$. The $\mathrm{Ca}$ is to be expected because of the dissolution of lime in the concrete. The $\mathrm{Na}, \mathrm{K}, \mathrm{Sr}$ and $\mathrm{Al}$ point to the alteration of feldspars, while the $\mathrm{Ti}, \mathrm{V}$, $\mathrm{Cr}$, and $\mathrm{Fe}$ indicate the alteration of ferromagnesian minerals, and the $\mathrm{Cu}$ and $\mathrm{S}$ indicate the alteration of sulphides in the rock fraction of the concrete (Golab \& Carr 2004).

The two samples containing zeolites released high quantities of $\mathrm{Mg}$, as can be expected because the zeolites occurred in a mafic rock type. Both also released $\mathrm{Ca}$, indicating the presence of calcium carbonates and/or laumontite, which incorporates exchangeable calcium.

The two slags released a high level of $\mathrm{Ca}$, and trace levels of Al, both of which are key components of blast furnace slag (Table 2). The air-cooled blast furnace slag also released high levels of $\mathrm{K}$ and $\mathrm{S}$ and elevated levels of $\mathrm{Ba}$, each of which are typically found in blast furnace slag.

Stage B Calcium concentrations follow a similar trend to $\mathrm{pH}$ in most cases (Fig. 6c). This indicates that the alkaline components of the reactive materials are probably related to calcium-bearing minerals. Conversely, the concentration of iron and aluminium in the samples is generally inverse to $\mathrm{pH}$ (Fig. 6a, b). This contrasts to the deionized water leachate tests, where the concentrations of iron and aluminium (Fig. 4) are independent of the $\mathrm{pH}$ because the solutions are within an $\mathrm{Eh} / \mathrm{pH}$ stability field for iron and aluminium minerals. The concentration of these cations is higher in the original drain-water than any of the reactive materials, indicating that all of the reactive materials have removed some of the $\mathrm{Fe}$ and $\mathrm{Al}$ from solution through raising the $\mathrm{pH}$. The samples that performed poorly in the batch tests are Zeolite 7 and Breccia4 and these samples were discontinued from further tests.

Table 5 displays the composition of the supernatant for seven reactive materials 28 days after the batch tests commenced. All of the reactive materials considered in 


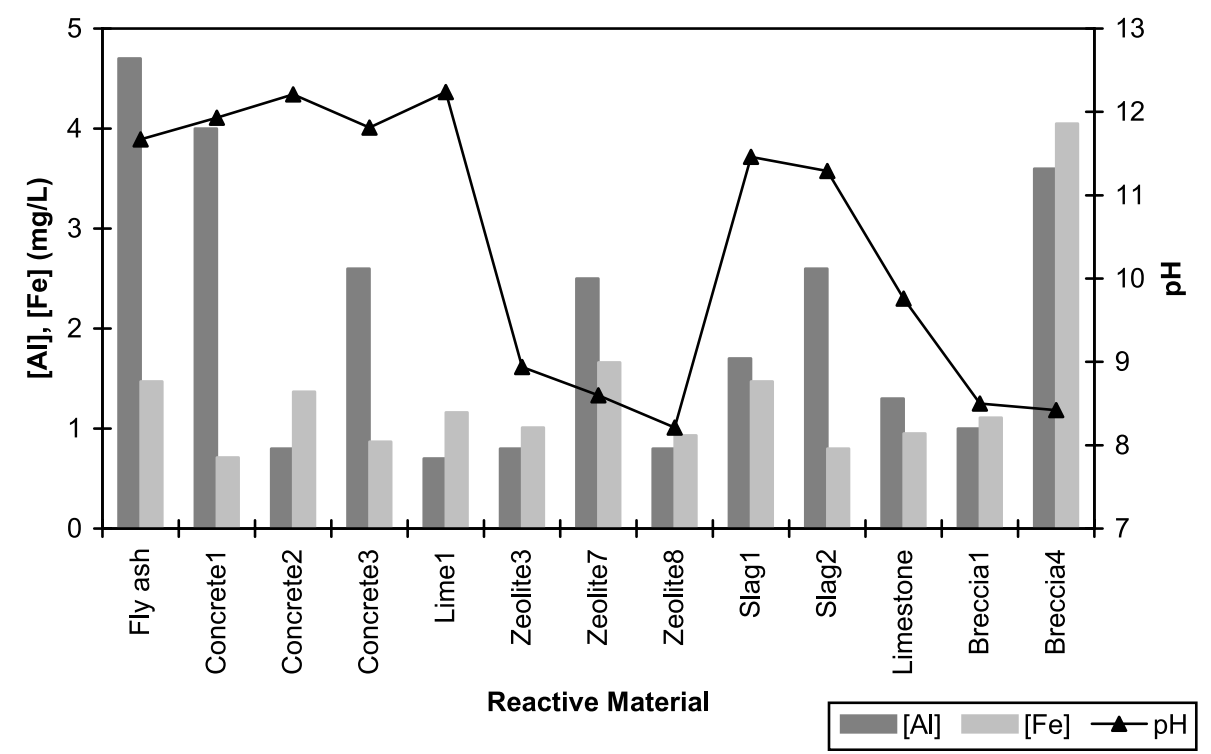

Fig. 4. Concentration of aluminium and iron and $\mathrm{pH}$ of all reactive materials after 28 days in leachate tests.

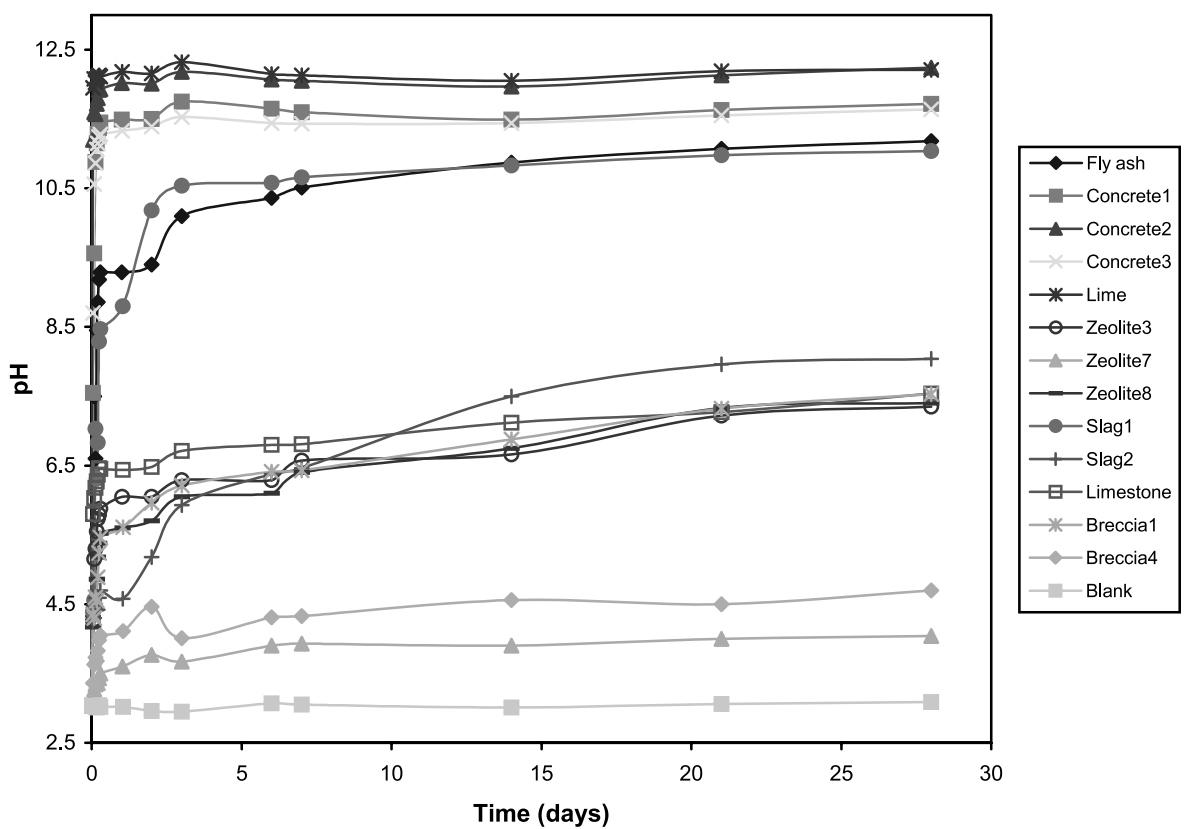

Fig. 5. Change in $\mathrm{pH}$ with time of the 13 reactive materials in drain-water and a drain-water blank for a total of 28 days.

Table 5 successfully removed at least $98 \%$ of the Fe and Al from the drain-water. All of the reactive materials also removed at least $98 \%$ of the Y, $57 \%$ of Co, $46 \%$ of $\mathrm{Zn}$, and $23 \%$ of $\mathrm{Mn}$ that was present in the drain-water. Some of the elements that were elevated in the leachate tests for some materials are also elevated in the batch tests, for example $\mathrm{Na}$ due to its high solubility, $\mathrm{Mg}, \mathrm{V}$ and $\mathrm{Cr}$ from ferromagnesian minerals, $\mathrm{K}$ and $\mathrm{Ba}$ from feldspars, and $\mathrm{Ca}, \mathrm{Mg}$ and $\mathrm{Sr}$ from carbonates. All elements were measured at concentrations below those allowed in waterways in NSW, Australia (State Pollution Control Commission 1972) (Table 7) and therefore are not of concern.

In terms of ability to increase $\mathrm{pH}$, the top performing reactive materials were Lime, Concrete1, 2, \& 3, Fly ash, and Slag1. The $\mathrm{pH}$ achieved by Lime in the batch tests is very similar to that predicted by Equation 2 (Fig. 5). Therefore, it is assumed that the performance of these six reactive materials is controlled by the amount of available lime. A grouping of reactive materials occurs with Limestone, these are Breccia1, and Zeolite $3 \&$ 8. The $\mathrm{pH}$ achieved by Limestone in the batch tests is close to that expected from Equation 8 (Fig. 5). It is therefore assumed that the performance of these four reactive materials is controlled by the abundance of available calcite. McElnea \& Ahern (2002) tested the potential for cement kiln dust to be used as a reactive material for a PRB. The mineralogy is dominated by calcite/aragonite and McElnea \& Ahern (2002) found that it is effective in raising groundwater $\mathrm{pH}$ and suppressing $\mathrm{Fe}$ and $\mathrm{Al}$ export. 

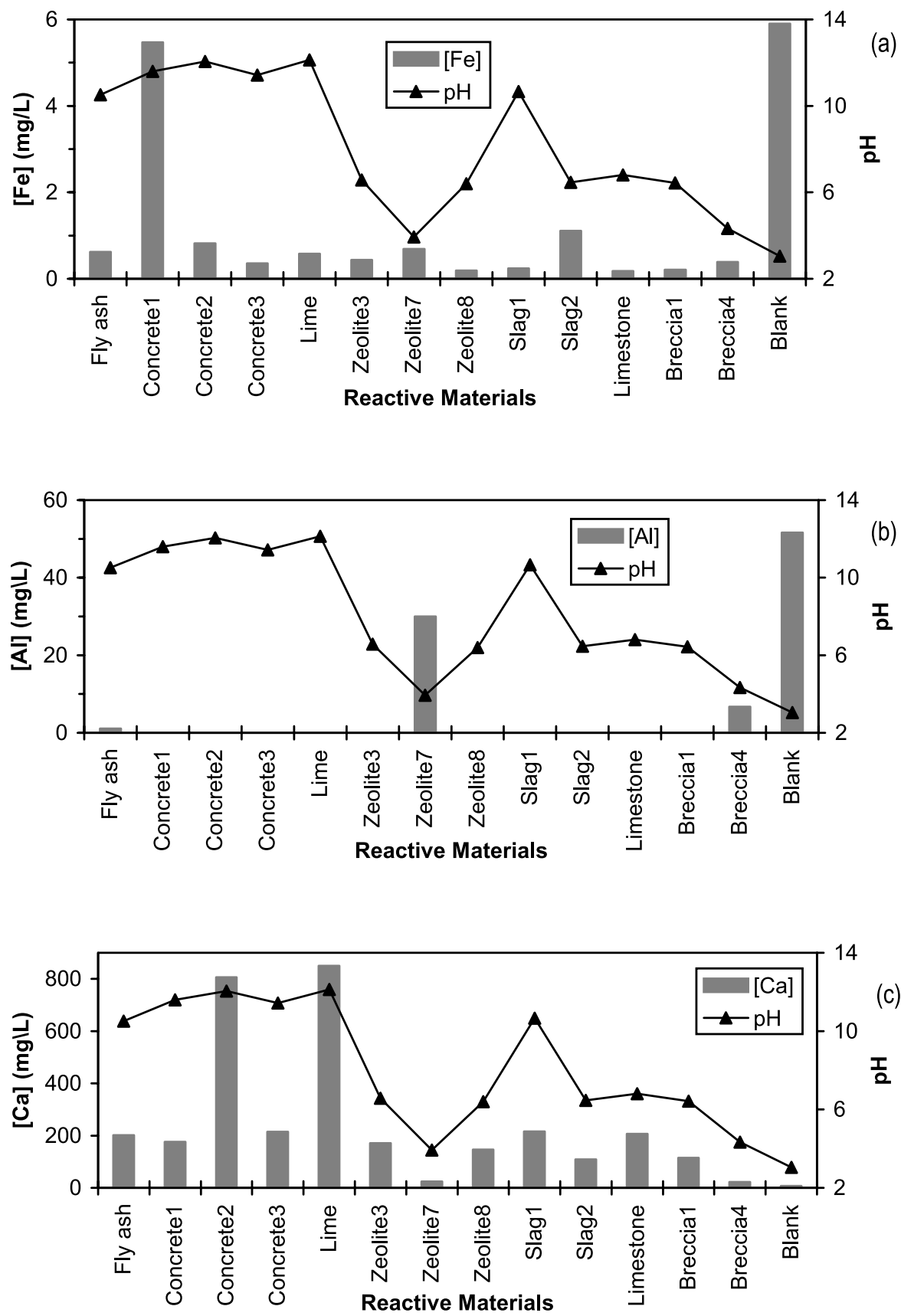

Fig. 6. The $\mathrm{pH}$ and the concentration of (a) iron, (b) aluminium, and (c) calcium in the batch tests after seven days.

It can be concluded that the behaviour of Lime and Limestone in the batch tests closely follows the theoretical behaviour predicted by the reaction kinetics. The Limestone does not raise the $\mathrm{pH}$ of the water above 7.0 because it is limited by the kinetics. This does not indicate that the Limestone is not an effective reactive material because for the field installation the $\mathrm{pH}$ of the groundwater does not need to be increased above neutral. A better indication of the usefulness of the calcite and lime containing materials may be gained by testing the exhaustion of neutralizing ability of the reactive materials against more than one volume of drain water, as was conducted in the third stage of batch tests.
To select the materials to be tested in the extended testing and the exhaustion of neutralizing ability tests, several factors were considered. Of the materials that performed well, Lime and Fly ash had been added for a comparison with another study but are not considered suitable for a PRB because of the small grainsize and cost of each. All three of the concretes performed very well. Of the three concretes, Concrete1 \& 2 are fresh unweathered concrete, whereas Concrete 3 is older recycled concrete and is more representative of the waste concrete that may be available for use in the PRB. Concrete 2 is a very young concrete that had not finished curing at the time of use in the batch tests, this accounts for the higher calcium content in the batch test for that 
sample. Even though Concrete1 \& 2 performed slightly better than Concrete3, it is the latter that will be considered further in the column tests because it is more representative of recycled concrete.

Zeolite 3 \& 8 were chosen to progress to the next round of testing because of their high $\mathrm{pH}$, low [Fe] and [Al] and relatively high [Ca]. Breccial performed reasonably well, and was chosen for the next phase of batch tests because it is weathered basalt and is a locally abundant material.

Zeolite7 and Breccia4 did not perform well in the batch tests and have three factors in common that can be recognized in hand specimens that may limit the neutralizing capacity. The first and most obvious factor is a relative paucity of the neutralizing minerals, primarily calcite and other carbonates. The second factor is the proportion of clays in the samples (Appendix 1). The third factor relates to the red colour caused by the presence of haematite. The three zeolitic materials that performed best are Zeolite $3 \& 8$ and Breccial, these three result in the lowest concentrations of $\mathrm{Fe}$ in the deionized water leach tests indicating they have the lowest level of available iron. It is postulated that haematite acts as a source of iron at low $\mathrm{pH}$ which leads to the formation of more acid through ferrolysis and hence counteracts the neutralization reactions of the carbonates.

The extended $\mathrm{pH}$ tests (Fig. 7) revealed a decline in $\mathrm{pH}$ in the supernatant from the GBFS (Slag2) with time, a slight decline in the $\mathrm{pH}$ in the supernatant from Concrete 3 and a continual steady rise in $\mathrm{pH}$ for the supernatant from both zeolitic materials. On this basis the GBFS was excluded from the exhaustion of neutralizing ability tests but the other six materials were carried through.

\section{Batch Test 3}

During the exhaustion of neutralizing ability tests (Fig. 8) nine new volumes of acidic drain-water were applied to the reactive materials. The $\mathrm{pH}$ achieved by all reactive materials declined markedly after the eighth application of acidic water, indicating that the materials were exhausted at this point. Problems with clogging by chemical precipitates would have been minimized in this test because the precipitates were removed prior to the addition of each new volume of acid water. The Limestone maintains a $\mathrm{pH}$ above 4.4 throughout the test and achieves a $\mathrm{pH}$ of 5 after the seventh application. The $\mathrm{pH}$ of the Concrete dramatically decreases after the second week by over three $\mathrm{pH}$ units to the neutral range. After the fifth week the Concrete has a $\mathrm{pH}$ above 4.5 and when this is compared to the drain-water $(\mathrm{pH}=3)$ it still represents more than a ten-fold decrease in acidity.

Based on the very small mass of reactive materials (100 g) and the large volume of water that was applied to the jars (approximately $5.4 \mathrm{~L}$ ), it is not surprising that 


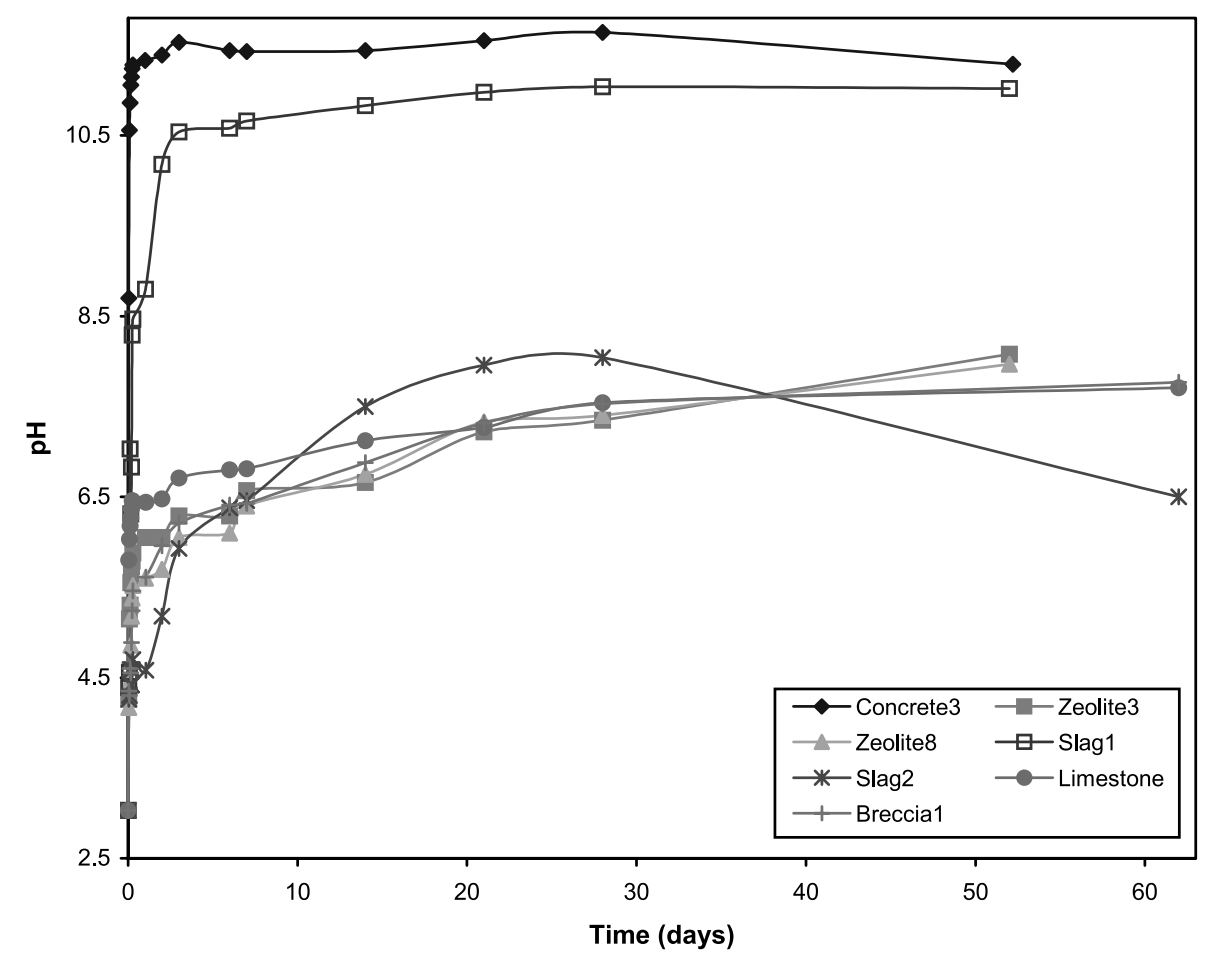

Fig. 7. Change in $\mathrm{pH}$ with time in the extended batch tests for the seven selected reactive materials.

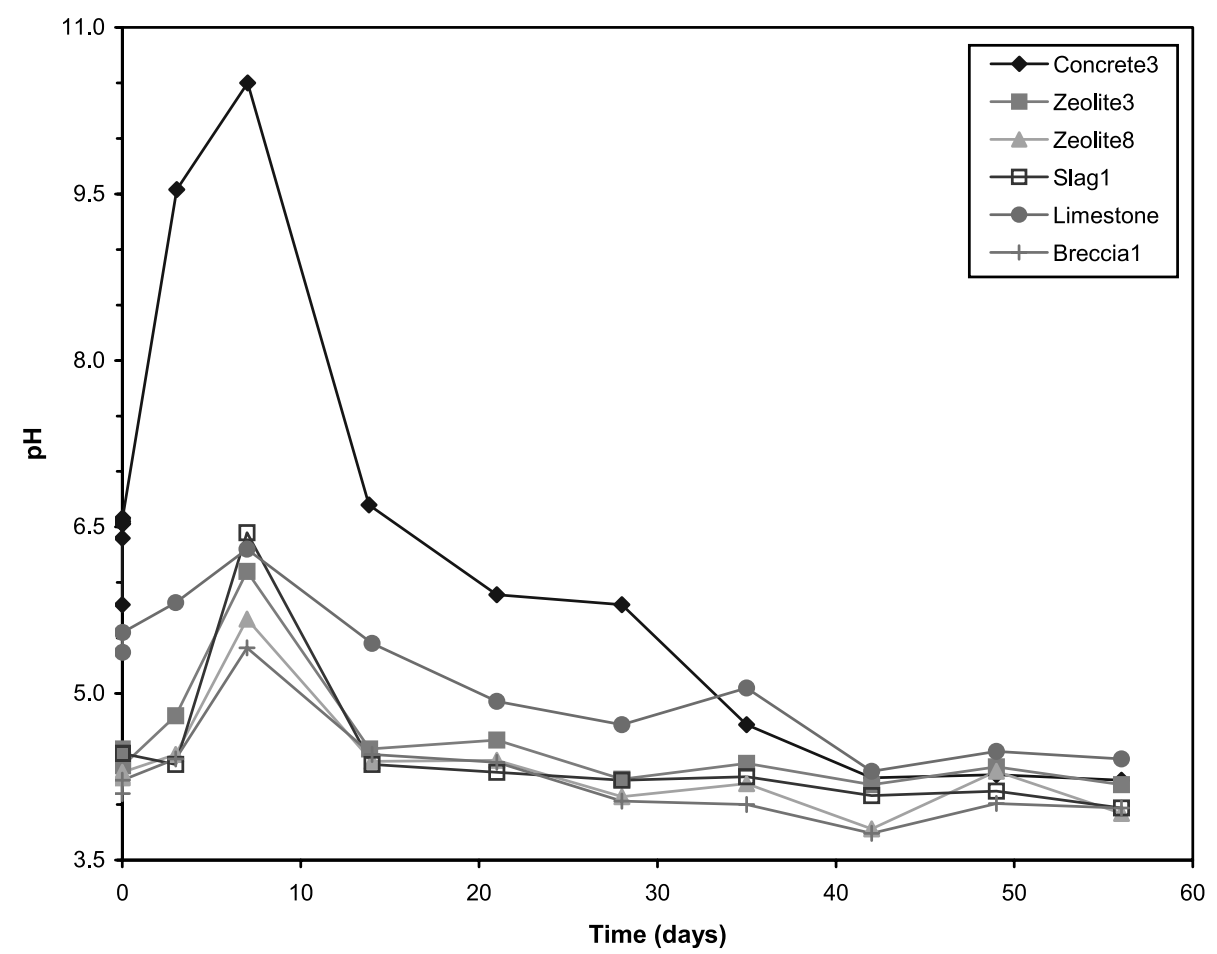

Fig. 8. Change in $\mathrm{pH}$ with time in the exhaustion of neutralizing ability test for the six selected reactive materials.

the reactive materials were diminished in terms of neutralizing capacity. The results from this final stage of batch tests will be fed into the modelling of the PRB to determine its lifetime. The recycled concrete will be tested in columns that simulate the flow conditions through the barrier.
The composition of the precipitates (Table 6) indicates the success of each reactive material in removing contaminants from the water. It also indicates which components can be leached out of the reactive materials then re-precipitated under suitable conditions. The precipitates generally contain a high level of $\mathrm{Al}$, which 
Table 7. An extract from Schedule two: restricted substances, of the Clean Waters Regulations, 1972 (State Pollution Control Commission 1972)

Substance Concentration (mg/L)

\begin{tabular}{lc} 
Arsenic & 0.05 \\
Barium & 1 \\
Boron* & 1 \\
Cadmium & 0.01 \\
Chloride* & 250 \\
Chromium (hexavalent) & 0.05 \\
Copper & 1 \\
Cyanide & 0.05 \\
Fluoride* & 1.5 \\
Iron (filtrable) & 0.3 \\
Lead & 0.05 \\
Manganese (filtrable) & 0.05 \\
Mercury & 0.001 \\
Selenium & 0.01 \\
Silver & 0.05 \\
Sulphate* & 250 \\
Uranyl ion & 5 \\
Zinc & 5 \\
\hline
\end{tabular}

* limits indicated do not apply to these substances in regard to tidal waters.

would have precipitated out of the drain-water as aluminium hydroxides, as reported by Ziemkiewicz et al. (1997) and/or hydroxysulphates, as is described by Nordstrom (1982). In each of the precipitates, the sulphur content indicates the precipitation of metal sulphides or aluminium hydroxysulphates and gypsum. However the concentrations are not high enough to account for all of the cations in the precipitates, indicating the parallel formation of (oxy)hydroxides. The precipitation of calcium and its geochemically related cations may be as sulphates (e.g. gypsum), as reported by Bernier (2005). It is assumed that the remainder of the cations, including $\mathrm{Fe}$, precipitated out of solution as metal (oxy)hydroxides or adsorbed onto the surface of the reactive materials, as was found by Gibert et al. (2003).

\section{Suitability of waste materials}

The highest priority of this research is to identify the most suitable alkaline material to remediate the acidic groundwater. The conclusion of this study is that the most suitable material is recycled concrete because it is:

(i) a waste material;

(ii) capable of neutralizing the acidity and removing $\mathrm{Fe}$ and $\mathrm{Al}$ from the groundwater;

(iii) coarse grained to encourage flow through the barrier; and

(iv) not a material that releases toxins into the environment. 
Even though the NSW ASS management guidelines (Stone et al. 1998) recommend the use of lime for remediating ASS, it is not suitable for use in a PRB due to its very fine-grained nature, which leads to problems with clogging. Similarly, although fly ash performed very well in the batch tests it is also too fine-grained, and can be easily eroded from a PRB. The recycled concretes achieved similar results to Lime and Fly ash in terms of neutralizing the acidity and removing the $\mathrm{Fe}$ and $\mathrm{Al}$ ions from solution (Fig. 4). This indicates that recycled concrete can perform as well as lime but at a fraction of the cost, and it is therefore the most suitable material for the barrier.

Caution should be exercised when selecting waste materials for use in an acidic environment, because of factors such as the toxicity of acid-soluble components and the physical properties of the material. Each of the waste materials tested in this project is already utilized in the construction industry but it cannot be assumed that the materials are environmentally safe based purely on prior usages. Some causes for caution amongst the waste materials considered in this paper include:

(i) the risk of acid-leachable toxins in the aggregate of recycled concrete;

(ii) concrete may contain steel reinforcing and therefore may not be crushable;

(iii) the zeolite laumontite crumbles into a powder when it completely dries and further study is required into whether this limits the usefulness of the volcanic breccia in a PRB if a drought occurs;

(iv) blast furnace slag usually contains soluble components within its fabric that may be gradually released if wetting and drying occurs within the barrier. In the batch tests however, neither of the slags released levels of substances in excess of the Clean Waters Regulations (Table 7); and

(v) slag is pozzolanic, hence can harden (cementation) with time and this would severely affect the flow through the barrier.

These examples illustrate that, if previous studies of the behaviour of the material under consideration in acidic aqueous conditions are not available in the literature, then it should be rigorously tested across the wide range of $\mathrm{pH}$ and $\mathrm{Eh}$ conditions that may occur in the barrier to ensure that toxins will not be released into the environment.

\section{Conclusions}

A permeable reactive barrier (PRB) is a most appropriate option for remediating groundwater from low-lying ASS. The suitability of alkaline materials for use in the construction of such a PRB was assessed using batch tests, including leaching tests in deionized water, batch tests in acidic drain-water and exhaustion of neutralizing ability tests. Based on the test results, the waste materials that are considered suitable for use in a PRB to treat ASS are recycled concrete, air-cooled blast-furnace slag and zeolitic breccia. Each of these materials fit the selection criteria because they neutralize acidity, remove $\mathrm{Al}$ and $\mathrm{Fe}$ ions from the groundwater and are locally abundant waste materials with a suitable grain size. The material that performed best was recycled concrete. Some materials were considered unsuitable for a variety of reasons including: excessively small grain size (lime and fly ash); insufficient neutralization of acidity and insufficient removal of $\mathrm{Fe}$ and $\mathrm{Al}$, (some volcanic breccia); or poor ability to neutralize acid (granulated blast furnace slag). This paper has demonstrated that certain waste products have appropriate properties to act as reactive materials in a PRB for remediation of acidic leachate from acid sulphate soil terrains. Each of the successful materials also comply with environmental restrictions (e.g. State Pollution Control Commission 1972) that are imperative in the operation of PRBs.

Following on from the batch tests, column tests are being conducted to simulate natural flow conditions through the PRB, to assist in the design of the PRB. Recycled concrete is being tested and the results of the column tests will allow the calculation of the required retention time in the PRB. A mixture of reactive materials could be considered because there may be synergies involved in combining different materials, such as recycled concrete and limestone. The results presented here have implications for groundwater cases other than acid sulphate soils. For example, the same reactive materials could be used to treat acid mine drainage.

Acknowledgements. We gratefully acknowledge the funding from the ARC for LP0348541 grant and the industry partners Shoalhaven City Council, care of Warwick Papworth, and the Manildra Group, care of Glenys Lugg. The ICPAES analyses were funded by the Australian Institute of Nuclear Science and Engineering. The authors thank Dr. Chris Waring from ANSTO for his input to the research. 


\section{Appendix 1. Description of the 13 reactive materials used in the batch tests. The tests that each material participated in are denoted using a}

Sample

Fly ash

Concrete1

Concrete2

Concrete3

Lime

Zeolite3

Zeolite7

Zeolite8

Slag1 Slag

Slag2 Slag

Limestone Limestone

Breccial Pink weathered latite

Breccia4 Red weathered latite
Description

Powdered fly ash

Fresh concrete

Fresh concrete

Recycled concrete

Powdered lime $\left[\mathrm{Ca}(\mathrm{OH})_{2}\right]$

Fluidal green-purple latite with

flattened vesicles containing white-pink laumontite

Dark red laumontite \& green clay-rich latite, minor veins of white laumontite

Amygdales with calcite cores \&

laumontite within altered red-grey

latite

Air-cooled blast furnace slag (ACBFS)

Granulated blast furnace slag (GBFS)

Large calcite grains indicate

metamorphism

Pink-red weathered latite with

coherent, chloritic amygdales \&

carbonate veins

Pink-red weathered latite of varied

coherency with clay, laumontite, calcite \& chloritic amygdales
BatchTest 1 BatchTest 2 BatchTest 3

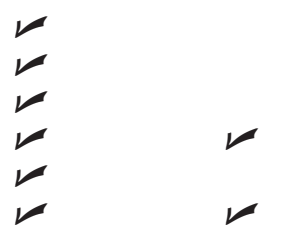

\section{References}

Amos, P.W. \& Younger, P.L. 2003. Substrate characterisation for a subsurface reactive barrier to treat colliery spoil leachate. Water Research, 37 (1), 108-120.

BAes, C.F. \& Mesmer, R.E. 1976. The Hydrolysis of Cations. Wiley-Interscience, New York.

Bernier, L.R. 2005. The potential use of serpentinite in the passive treatment of acid mine drainage: Batch experiments. Environmental Geology, 47 (5), 670-684.

Chou, L., Garrels, R.M. \& Wollast, R. 1989. Comparative study of the kinetics and mechanisms of dissolution of carbonate minerals. Chemical Geology, 78, 269-282.

Desmier, R., MacDonald, B.C.T., Melville, M.D. \& Waite, T.D. 2002. Design, construction and performance of passive and active treatment systems to decrease the acidity export from acid sulfate soils in the Tweed Shire, NSW (Australia). In: Bush, R. (ed.) Proceedings of the 5th International Acid Sulfate Soils Conference - Sustainable Management of Acid Sulfate Soils. Tweed Heads, Australia, 71-72.

Gibert, O., de Pablo, J., Cortina, J.L. \& Ayora, C. 2003. Evaluation of municipal compost/limestone/iron mixtures as filling material for permeable reactive barriers for in-situ acid mine drainage treatment. Journal of Chemical Technology \& Biotechnology, 78 (5), 489-496.

Golab, A.N. \& CARR, P.F. 2004. Changes in geochemistry and mineralogy of thermally altered coal, Upper Hunter Valley, Australia. International Journal of Coal Geology, 57 (3-4), 197-210.

Indraratna, B., Glamore, W., Blunden, B., Downey, J. \& Tularam, A. 2001. Engineering strategies for controlling problems of acid sulphate soils in low-lying coastal areas. In: Smith, D.W., Fityus, S.G. \& Allman, M.A. (eds)
Proc. 2nd Australia and New Zealand Conference on Environmental Geotechnics. Australian Geomechanics Society Inc, Newcastle, Australia, 133-146.

Indraratna, B., Golab, A., Glamore, W. \& Blunden, B. 2005. Acid sulphate soil remediation techniques on the Shoalhaven River Floodplain, Australia. Quarterly Journal of Engineering Geology and Hydrogeology, 38, 129-142.

JaCoBs, P.H. \& Forstner, U. 1999. Concept of subaqueous capping of contaminated sediments with active barrier systems (ABS) using natural and modified zeolites. Water Research, 33 (9), 2083-2087.

JACOBS, P.H. \& WaITE, T.D. 2004. The role of aqueous iron(II) and manganese(II) in sub-aqueous active barrier systems containing natural clinoptilolite. Chemosphere, 54 (3), 313-324.

Lum, K.R. \& Bhupsingh, W.A.M. 1983. The Leaching of Some Elements of Environmental Importance in Blast Furnace and Steel Making Slags. NRWI contribution No. 83-18. National Water Research Institute, Environment Canada.

McElnea, A.E. \& Ahern, C.R. 2002. Testing the effectiveness of lime and cement kiln dust as acid sulfate soil ameliorants using leaching column experiments. In: BusH, R. (ed.) Proceedings of the 5th International Acid Sulfate Soils Conference - Sustainable Management of Acid Sulfate Soils. Tweed Heads, Australia, 167-168.

Muston, R. 1991. Monitoring of Selected Water Quality Indicators in Blast Furnace Slag Emplacement Leachate Discharge, and its Influence on Receiving Waters. Roslyn Muston and Associates Pty Ltd, Fairy Meadow, Australia.

Nordstrom, D.K. 1982. The effect of sulfate on aluminium concentrations in natural waters: some stability relations 
in the system $\mathrm{Al}_{2} \mathrm{O}_{3}-\mathrm{SO}_{3}-\mathrm{H}_{2} \mathrm{O}$ at $298 \mathrm{~K}$. Geochimica et Cosmochimica Acta, 46, 681-692.

Park, J.-B., Lee, S.-H., LeE, J.-W. \& Lee, C.-Y. 2002. Lab scale experiments for permeable reactive barriers against contaminated groundwater with ammonium and heavy metals using clinoptilolite (01-29B). Journal of Hazardous Materials, 95 (1-2), 65-79.

Peterson, M. 1999. Volcanic Breccias Within the Late Permian Lower Broughton Formation, Southern Sydney Basin, $N S W$. Honours Thesis. University of Wollongong, Wollongong.

Ring, R.J., TaPsell, G.J., Collier, D.E. \& Brown, P.L. 1996. A Report to WMC - Olympic Dam Operations on Neutralisation of Tailings Liquor for Recycle. Australian Nuclear Science and Technology Organisation Lucas Heights Science and Technology Centre, Chemical and Waste Engineering Section, Sydney.

SENDERov, E.E. 1988. Physical-chemical aspects of zeolite formation in nature. In: KALLO, D. \& SHERRY, H.S. (eds) Occurrence, Properties and Utilization of Natural Zeolites. Akadémiai Kiadó, Budapest.

Siriwardane, H.J., Kannan, R.S.S. \& Ziemkiewicz, P.F. 2003. Use of waste materials for control of acid mine drainage and subsidence. Journal of Environmental Engineering, 129 (10), 910-915.

Sirman Associates Limited 1985. Evaluation of Slag and its Potential Impact on the Aquatic Environment. Environmental Protection Service Environment, Canada.
State Pollution Control Commission 1972. Clean Waters Regulations.

Stone, Y., Ahern, C.R. \& Blunden, B. 1998. Acid Sulfate Soils Manual 1998. Acid Sulfate Soil Management Advisory Committee, Wollongbar, NSW, Australia.

VIDIC, R.D. 2001. Permeable reactive barriers: Case study review. Ground-Water Remediation Technologies Analysis Center, Pittsburgh.

Waybrant, K.R., Blowes, D.W. \& PtaceK, C.J. 1998. Selection of reactive mixtures for use in permeable reactive walls for treatment of mine drainage. Environmental Science \& Technology, 32 (13), 1972-1979.

White, I., Melville, M.D., Wilson, B.P. \& Sammut, J. 1997. Reducing acidic discharges from coastal wetlands in eastern Australia. Wetlands Ecology and Management, 5 (1), 55-72.

Wilkin, R.T., Puls, R.W. \& Sewell, G.W. 2003. Long-term performance of permeable reactive barriers using zerovalent iron: geochemical and microbiological effects. Ground Water, 41 (4), 493-503.

Ziemkiewicz, P.F., Skousen, J.G., Brant, D.L., Sterner, P.L. \& LoveTt, R.J. 1997. Acid mine drainage treatment with armored limestone in open limestone channel. Journal of Environmental Quality, 26 (4), 1017-1024. 